\title{
The hrpC and hrpN Operons of Erwinia chrysanthemi EC16 Are Flanked by plcA and Homologs of Hemolysin/Adhesin Genes and Accompanying Activator/Transporter Genes
}

\author{
Jihyun F. Kim, Jong Hyun Ham, David W. Bauer, Alan Collmer, and Steven V. Beer \\ Department of Plant Pathology, Cornell University, Ithaca, NY 14853, U.S.A. \\ Accepted 24 February 1998.
}

The hrpC operon of Erwinia chrysanthemi EC16 encodes five genes conserved in Erwinia amylovora and Pseudomonas syringae. Mutagenesis indicated that $\mathrm{hrcC}$ is required for elicitation of the hypersensitive reaction in tobacco leaves. The unexpected presence of $p l c A$ and homologs of hemolysin/activator genes in the regions flanking the $h r c C$ and $h r p N$ operons is reported.

Additional keywords: Bordetella, Hrp pathway, phospholipase C, type III secretion.

Clusters of hrp genes required both for elicitation of the hypersensitive reaction (HR) on nonhost plants and pathogenicity on host plants are conserved in many phytopathogenic bacteria (reviewed in Alfano and Collmer 1997). The majority of hrp genes encode components of a protein secretion system called the Hrp (type III) pathway. Some of the hrp secretion genes are widely conserved even among animal-pathogenic bacteria such as Yersinia, Salmonella, and Shigella spp.; these have been designated $h r c$ (Bogdanove et al. 1996a). The existence of $h r p / h r c$ genes in soft-rotting bacteria like E. carotovora and $E$. chrysanthemi, which do not normally induce the HR, was suggested based on Southern hybridization (Laby and Beer 1992). Furthermore, mutants of E. chrysanthemi EC16 deficient in pectate lyases were demonstrated to cause a typical HR (Bauer et al. 1994). To date, two $h r p / h r c$ genes, $h r p N$ and $h r c T$, have been identified from E. chrysanthemi (Bauer et al. 1994, 1995).

Among the proteins of the Hrp pathway, $\mathrm{HrcC}$ is of particular interest because it is a member of the broadly conserved PulD/pIV superfamily of proteins that function in outer-membrane translocation of both the type II and type III secretion pathways (Russel 1994). We characterized the genomic region of E. chrysanthemi EC16 encompassing the

Corresponding author: Steven V. Beer; Telephone: 1-607-255-7870; Fax: 1-607-255-4471; E-mail: svb1@ cornell.edu

The nucleotide sequence reported in this paper has been deposited in GenBank under accession number L39897, which contains the previously published $h r p N_{E c h}$ sequence (D. W. Bauer, Z.-M. Wei, S. V. Beer, and A. Collmer. Mol. Plant-Microbe Interact. 8:484-491, 1995). $h r p N$ gene and the $h r p C$ operon that contains the $h r c C$ gene, and compared it with the corresponding region of E. amylovora. We report here (i) similarities in the hrp systems of two bacterial plant pathogens that employ different attack strategies, (ii) evidence that $h r c C$ is required by E. chrysanthemi to elicit the HR, (iii) the discovery of $h r p$-linked potential virulence genes seemingly unrelated to the Hrp system, and (iv) evidence that this gene arrangement is conserved among diverse strains of $E$. chrysanthemi.

Sequence analysis of Hrp mutants indicated that $h r p N$ and $h r c U$ mark the ends of the hrp gene cluster of E. amylovora, and that $h r c T$ is situated upstream of $h r c U$ (Wei et al. 1992; Wei and Beer 1993; Bogdanove et al. 1996b). Based on the presence of both $h r p N$ and $h r c T$ together in individual cosmid clones, pCPP2156, pCPP2157, and pCPP2158 (data not shown), the $h r p / h r c$ genes of E. chrysanthemi EC16 also seemed clustered and, therefore, $h r c C$ was likely to be contained in these cosmids. Southern hybridization was used to confirm the presence of $h r c C$ in the three cosmids. The cosmids were digested with BamHI or SalI, and then incubated with the ${ }^{32} \mathrm{P}$-labeled, 2.1-kb BamHI-HpaI fragment from pCPP1036 that contains hrcC of E. amylovora Ea321 (Kim et al. 1997). Restriction fragments of 8 to $11 \mathrm{~kb}$ in size from each cosmid hybridized to the probe (data not shown). One of them, the 8.2-kb SalI fragment of pCPP2157, was the insert of pCPP2142 that had been constructed to isolate $h r p N_{E c h}$ (Bauer et al. 1995).

The nucleotide sequence upstream of $h r p N_{E c h}$ in pCPP2142 was determined with an ABI 373A automated DNA sequencer by the DNA Sequencing Facility of the Cornell University Biotechnology Program, using synthesized primers. An apparent five-cistronic operon, which is preceded by an HrpLdependent promoter-like sequence, GGAACC-N ${ }_{15}$-CCACAC AA, was identified and named $h r p C$ (Fig. 1A). Open reading frames (ORFs) in $h r p C$, designated $h r p F, h r p G, h r c C$, $h r p T$, and $h r p V$, were remarkably similar and collinear to corresponding ORFs in the hrpC operons of E. amylovora and $P$. syringae (Kim et al. 1997; Huang et al. 1992, 1995; W.-L. Deng, G. Preston, H.-S. Huang, and A. Collmer, in preparation) (Table 1). Among the five encoded proteins in the $h r p C$ operon of the three bacteria, $\mathrm{HrcC}$ showed the highest amino 
acid identities. HrpT has an N-terminal lipoprotein signal peptide, and it could be a periplasmic chaperone for $\mathrm{HrcC}$, as in type II secretion systems (Hardie et al. 1996). As in $E$. amylovora and E. chrysanthemi, the 5' region of hrpN of E. carotovora subsp. carotovora (Mukherjee et al. 1997) contains $h r p V_{E c c}$ (J. F. Kim, personal observation), indicating conservation of the location of the $h r p C$ operon relative to $h r p N$ among the three Erwinia spp.

To determine the role of $h r c C_{E c h}$ in HR elicitation, a nonpolar $h r c C$ mutant was generated by marker exchangeeviction mutagenesis (Ried and Collmer 1987) of CUCPB5006, a PelABCE ${ }^{-}$derivative of E. chrysanthemi EC16 that causes a typical HR in tobacco leaves (Bauer et al. 1994). The 3.9-kb BamHI-EcoRI fragment of pCPP2142, which contains the entire $h r p C$ operon, was cloned into $\mathrm{pBC}$ SK (-) and pBluescript II KS (-) (Stratagene, La Jolla, CA), producing pCPP1221 and pCPP2355, respectively (Fig. 1A). pCPP1221 was digested with NarI to eliminate most of $h r c C$, the protruding ends were filled in with $\mathrm{dGTP} / \mathrm{dCTP}$ (PerkinElmer, Branchburg, NJ) and the Klenow fragment (Boehringer Mannheim, Indianapolis, IN) to make the $h r c C$ deletion in frame, and the deleted region was replaced with the $n p t I-s a c B$ -

Table 1. Comparison of proteins in the hrpC operon of Erwinia chrysanthemi EC16 with the corresponding proteins of Erwinia amylovora and Pseudomonas syringae pv. syringae

\begin{tabular}{|c|c|c|c|c|c|}
\hline \multirow[b]{2}{*}{ Bacterium } & \multicolumn{5}{|c|}{$\begin{array}{l}\text { Protein amino acids similar/identical } \\
(\% / \%) \text { with those of } E \text {. chrysanthemi }\end{array}$} \\
\hline & $\begin{array}{l}\text { HrpF } \\
{[75]^{b}}\end{array}$ & $\begin{array}{l}\text { HrpG } \\
{[144]}\end{array}$ & $\begin{array}{l}\text { HrcC } \\
{[691]}\end{array}$ & $\underset{[61]}{\text { HrpT }}$ & $\begin{array}{l}\text { HrpV } \\
{[136]}\end{array}$ \\
\hline E. amylovora & $76 / 62$ & $57 / 39$ & $82 / 69$ & $65 / 48$ & $55 / 39$ \\
\hline P. syringae pv. syringae & $47 / 26$ & $39 / 21$ & $69 / 48$ & $58 / 37$ & $48 / 21$ \\
\hline
\end{tabular}

A

E. amylovora

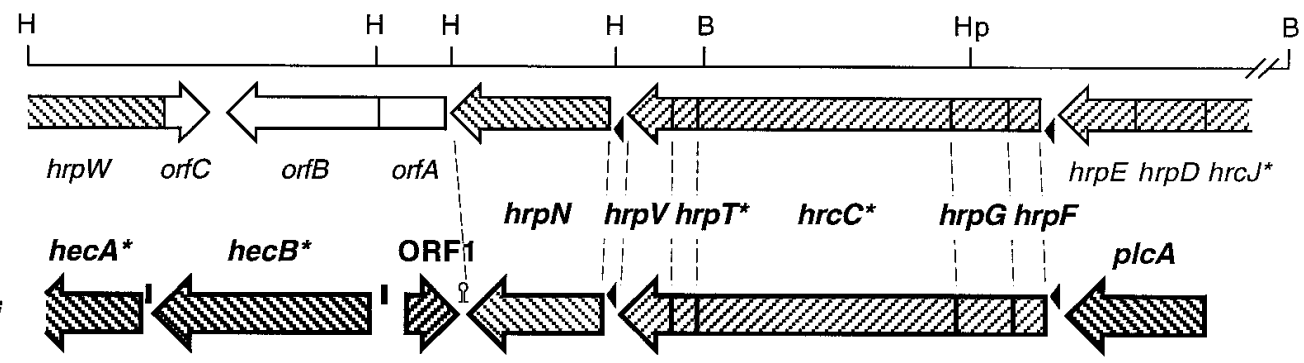

E. chrysanthemi
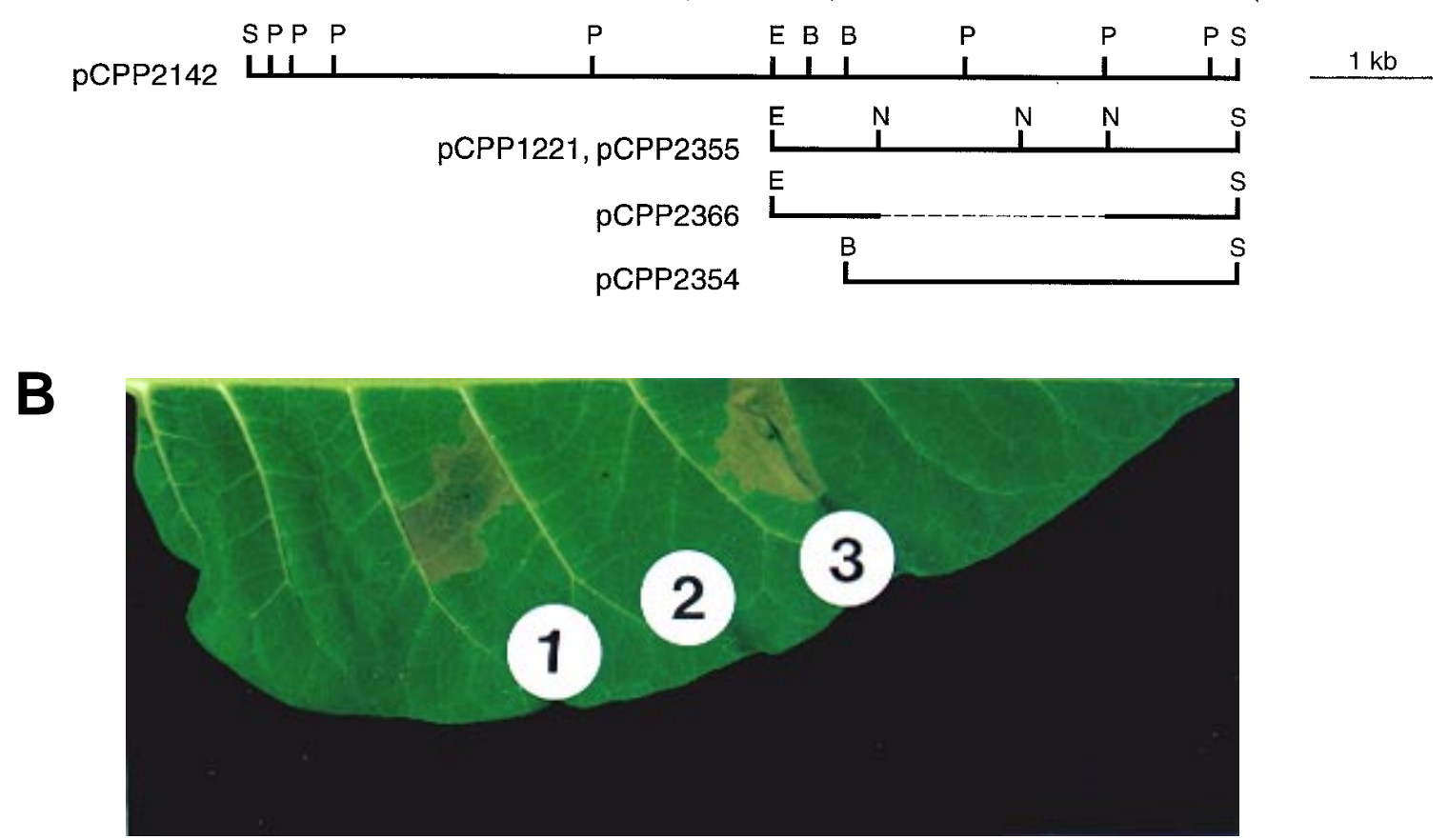

Fig. 1. The $h r p C$ and $h r p N$ region of Erwinia chrysanthemi EC16 and the requirement of $h r c C$ for hypersensitive reaction (HR) elicitation. A, Genetic organization of the $h r p C$ and $h r p N$ region of E. chrysanthemi EC16 (Keen et al. 1992; Bauer et al. 1995; this study) and subclones used for sequencing and marker-exchange mutagenesis. Corresponding region in E. amylovora (Wei et al. 1992; Kim et al. 1997; Kim 1997) is shown for comparison. Directions of transcription indicated by arrow boxes. Filled triangles are putative HrpL-dependent promoters; vertical black bars are KdgR-box-like sequences. The hairpin indicates a putative transcription terminator site. Open reading frames indicated by asterisks contain potential signal peptides in their deduced protein sequences. Restriction enzymes: H, HindIII; B, BamHI; Hp, HpaI; P, PstI; S, SalI; N, NarI. B, Tobacco leaf showing effect of nonpolar $h r c C$ mutation. Panels: 1, CUCPB5006 (contains intact $h r p C$ ); 2, CUCPB5089 ( $h r c C$ mutant); 3, CUCPB5089(pCPP2354; contains $h r p F G h r c C$ ). Leaf was photographed $24 \mathrm{~h}$ after infiltration. 
Table 2. Comparison of HecB and HecA with homologs ${ }^{\mathrm{a}}$

\begin{tabular}{|c|c|c|c|c|c|c|c|}
\hline \multirow[b]{2}{*}{$\begin{array}{l}\text { Erwinia chrysanthemi } \\
\text { proteins }\end{array}$} & \multicolumn{7}{|c|}{$\begin{array}{l}\text { Bacteria containing homologs of } \mathrm{HecB} \text { and } \mathrm{Hec} A \text {, } \\
\text { and similar/identical amino acid percentages of the homologous proteins }\end{array}$} \\
\hline & $\begin{array}{l}\text { Bordetella } \\
\text { pertussis }\end{array}$ & $\begin{array}{l}\text { Serratia } \\
\text { marcescens }\end{array}$ & $\begin{array}{l}\text { Edwardsiella } \\
\quad \text { tarda }\end{array}$ & $\begin{array}{l}\text { Proteus } \\
\text { mirabilis }\end{array}$ & $\begin{array}{l}\text { Haemophilus } \\
\text { ducreyi }\end{array}$ & $\begin{array}{l}\text { Haemophilus } \\
\text { influenzae }\end{array}$ & $\begin{array}{l}\text { Haemophilus } \\
\text { influenzae }\end{array}$ \\
\hline HecB & FhaC (49/26) & ShlB (47/30) & EthB (49/28) & HpmB (48/26) & HhdB (50/24) & HMW2B (45/22) & HxuB (46/20) \\
\hline $\mathrm{Hec}^{\mathrm{b}}$ & FhaB (63/44) & ShlA (60/39) & EthA $(56 / 38)$ & $\operatorname{HpmA}(51 / 37)$ & HhdA (52/33) & HMW2A (51/26) & HxuA (48/23) \\
\hline
\end{tabular}

a Determined by BESTFIT program (GCG software package, version 7.3).

b Only the N-terminal 258 amino acids of HecA were compared.

HecB-Ech

Fhac-Bpe

ShlB-Sma

HecB-Ech

FhaC-Bpe

ShlB-Sma

HecB-Ech

Fhac-Bpe

ShlB-Sma

HecB-Ech

FhaC-Bpe

ShlB-Sma

HecB-Ech

Fhac-Bpe

ShlB-Sma

HecB-Ech

FhaC-Bpe

Sh1B-Sma

HecB-Ech

FhaC-Bpe

Sh1B-Sma

HecB-Ech

Fhac-Bpe

ShlB-Sma

HecB-Ech

Fhac-Bpe

ShlB-Sma

HecB-Ech

Fhac-Bpe

Sh1B-Sma

HecB-Ech

Fhac-Bpe

ShlB-Sma

HecB-Ech

Fhac-Bpe

ShlB-Sma

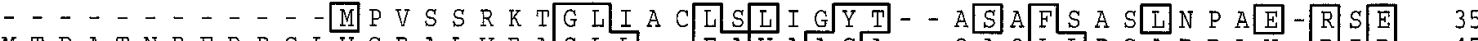

M T D A T N R F R P G L V G A L V R A G L L - - F A V A A C A - - Q A Q L L P G A R D L N

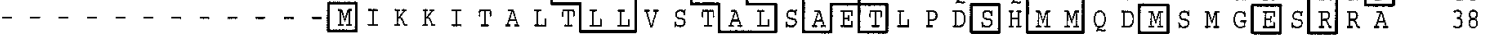

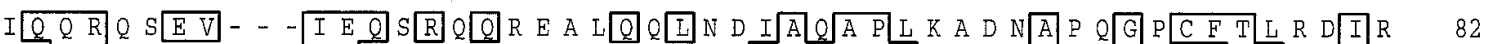

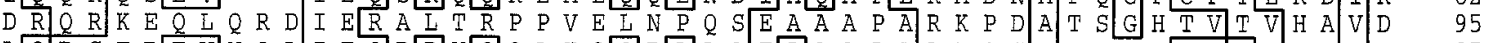
L Q

F N H ST T L L R P S D O A T L V A G Y L N R C N N L E Q I N R L V H D V S S N W W I Q R G Y I T S R A 132

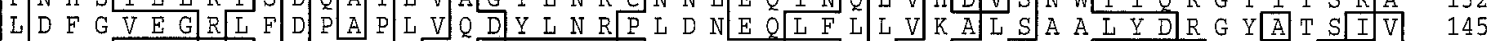

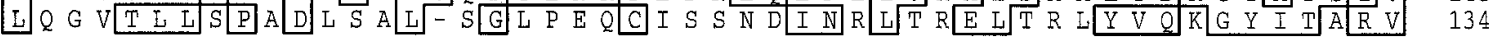

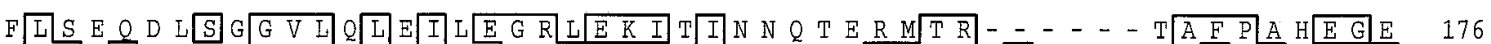

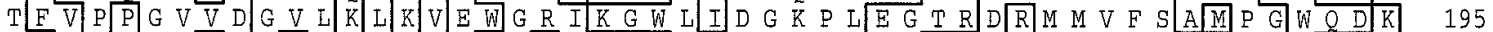

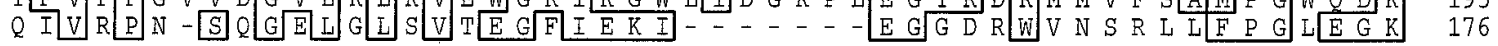

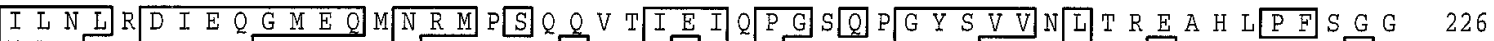

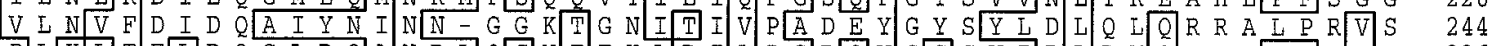

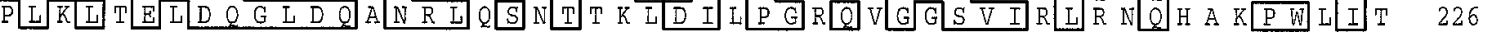

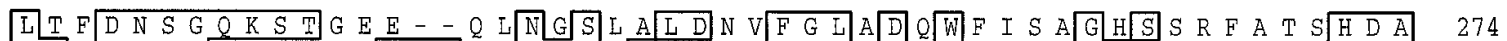

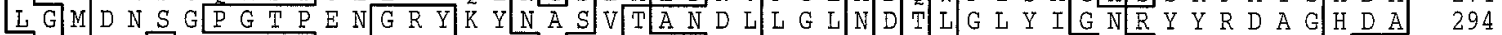

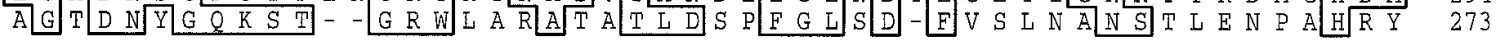

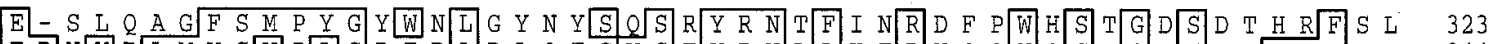

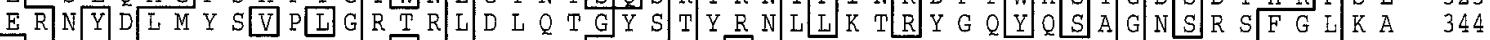

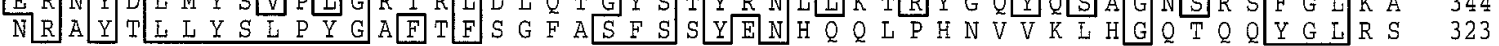

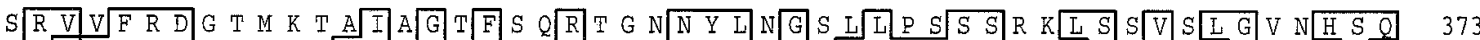
$T$ R L L Y R D T R S Q F S V Y G G L K ILR Q N K N Y L A G T R L D V S S K H Y S D V T V G M Q Y S T 394

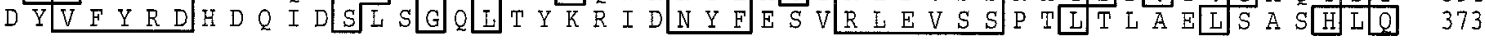

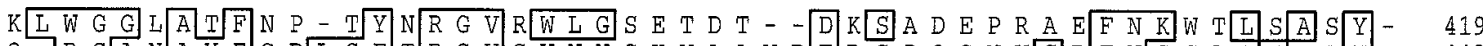

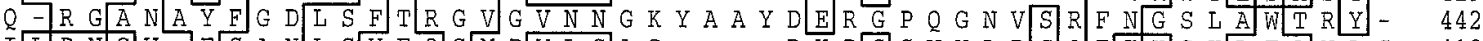

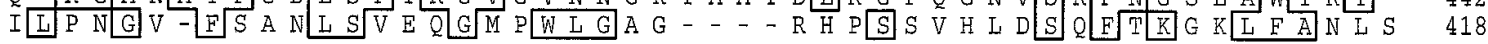

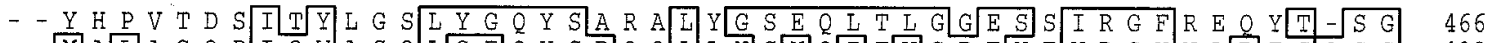

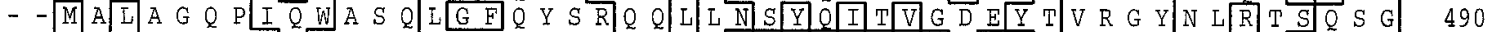

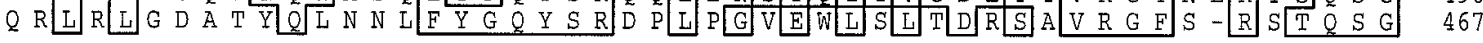

N R G A Y R R NE⿵冂卄.

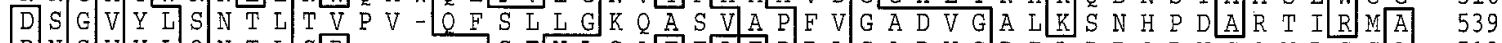

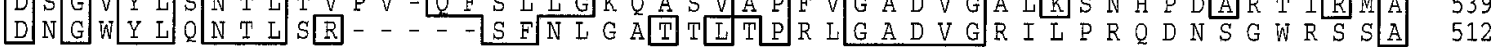

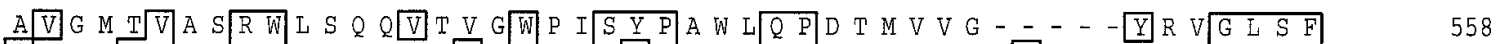

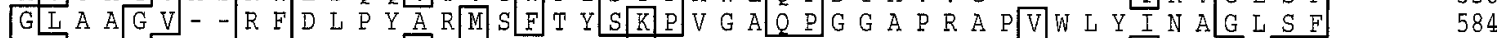

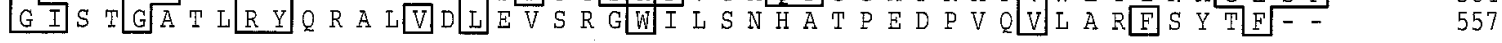

Fig. 2. Alignment of HecB and its homologs by PILEUP program (GCG software package, version 7.3) with default parameters. Ech, Erwinia chrysanthemi; Bpe, Bordetella pertussis; Sma, Serratia marcescens. 
sacR cartridge, which confers $\mathrm{Km}$ resistance and sucrose sensitivity to create the $h r c C_{E c h}: n p t I-s a c B$-sacR plasmid pCPP2365. This plasmid was electroporated into E. chrysanthemi CUCPB5006 with a Gene Pulser (BioRad, Richmond, $\mathrm{CA})$ and subsequently marker exchanged into the CUCPB5006 chromosome to produce CUCPB5088 $\left(\mathrm{Km}^{\mathrm{r}}\right.$, $\mathrm{Suc}^{\mathrm{s}}$ ). A similar $\Delta h r c C$ construct, pCPP2366, was made by digestion with NarI, end filling, and self-ligation of pCPP2355 (Fig. 1A). pCPP2366 was then electroporated into CUCPB5088 and introduced into the chromosome through double cross-over. One of the $\mathrm{Km}^{\mathrm{s}}$, $\mathrm{Ap}^{\mathrm{s}}$, and $\mathrm{Suc}^{\mathrm{r}}$ colonies, which has a 1,905-bp in-frame deletion of $h r c C$, was designated CUCPB5089. To assay in tobacco, CUCPB5089 was grown on King's B plates (King et al. 1954) for $24 \mathrm{~h}$, and the colonies were suspended to approximately $5 \times 10^{8} \mathrm{CFU} / \mathrm{ml}$ in $5 \mathrm{mM}$ morpholino-ethanesulfonic acid, $\mathrm{pH}$ 6.5. Tobacco leaves (cv. Xanthi) infiltrated with CUCPB5089 did not exhibit the HR, demonstrating that $h r c C$ is required for HR elicitation (Fig. 1B). Transformation of the mutant with pCPP2354, which carries $h r p F, h r p G$, and $h r c C$, restored the $\mathrm{HR}$, indicating the nonpolar nature of the mutation.

A

M $122344566780101112131415161718 M$

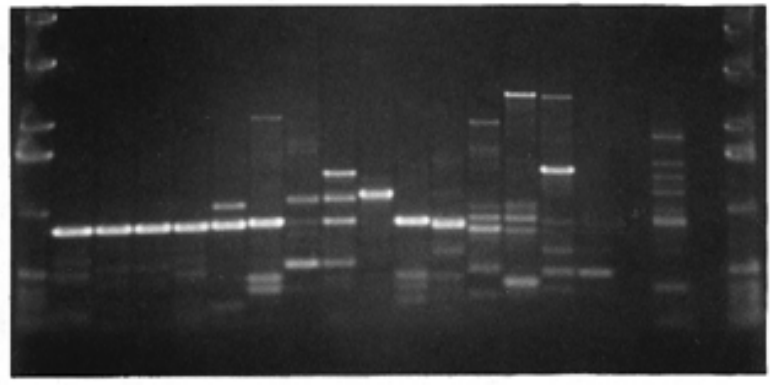

B
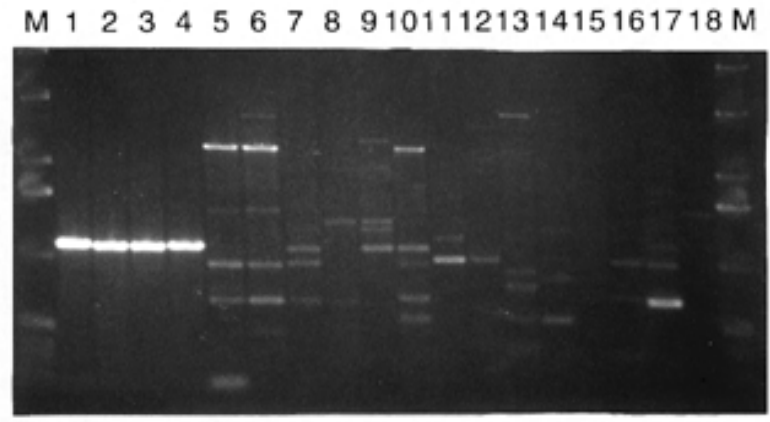

Fig. 3. Polymerase chain reaction amplification of DNA between (A) plcA and $h r p F$, and (B) $h r p N$ and $h e c B$. Chromosomal DNA used from: Erwinia chrysanthemi strains EC16 (lane 1), ATCC27385 (lane 2), NCPPB1861 (lane 3), NCPPB427 (lane 4), NCPPB2543 (lane 5), 113-2 (lane 6), CFBP1448 (lane 7), CUCPB1237 (lane 8), 0-596 (lane 9), PDDCC2349 (lane 10), 3937 (lane 11), 4227 (lane 12); E. carotovora subsp. atroseptica ATCC33260 (lane13); E. carotovora subsp. carotovora strains ATCC15713 (lane 14), DB17 (lane 15); E. stewartii DC283 (lane 16); E. amylovora Ea321 (lane 17); and E. herbicola Eh252 (lane 18). M indicates 1-kb DNA ladder (Life Technologies, Gaithersburg, MD).
Sequence analysis upstream of $h r p C_{E c h}$ revealed $p l c A$, the gene encoding phospholipase $\mathrm{C}$ (Keen et al. 1992) (Fig. 1A). In E. amylovora and $P$. syringae, the comparable location is occupied by another hrp secretory operon (Kim et al. 1997; Huang et al. 1995). Differences were also evident in the region downstream of $h r p N_{E c h}$. The deduced translation product of the ORF that is transcribed convergent to $h r p N$, designated ORF1, showed similarity to proteins that are involved in biosynthesis of aromatic polyketides such as CurC of Streptomyces curacoi (50\% similar, 26\% identical) (Bergh and Uhlen 1992).

BLAST searches (Altschul et al. 1990) of the two ORFs next to ORF1 (Fig. 1A) indicated homology to $\mathrm{Ca}^{2+}$ independent hemolysins and the outer-membrane hemolysin activator/transporter proteins of several Proteobacteria (Hirono et al. 1997 and references therein) (Table 2). These ORFs were named hecA (hemolysin homolog) and hecB (hemolysin activator/transporter homolog), after ORFs en-

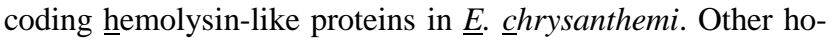
mologs of HecA and $\mathrm{HecB}$ included adhesins and accessory processing proteins such as $\mathrm{FhaB} / \mathrm{FhaC}$ of Bordetella pertussis and HMWA/HMWB of nontypeable Haemophilus influenzae (Willems et al. 1994; Barenkamp and St. Geme 1994). Both $\mathrm{Hec} \mathrm{A}$ and $\mathrm{HecB}$ contained potential N-terminal signal peptides. HecB was predicted to contain many amphiphilic $\beta$ sheets that could form a $\beta$-barrel, and the sequence ended with phenylalanine, which is typical of outer-membrane proteins (Fig. 2). The N-terminal, 258-amino-acid portion of HecA was most similar to FhaB of $B$. pertussis, which is processed into filamentous hemagglutinin (Makhov et al. 1994). In animalpathogenic bacteria, phospholipases, hemolysins, and adhesins have been implicated as important pathogenicity/virulence determinants. However, Keen and colleagues (1992) reported that a plcA mutant exhibited the same degree of virulence as the wild-type strain on potato tubers and in chrysanthemum stems. The role, if any, of the plcA, hecB, and hecA products in the virulence of $E$. chrysanthemi is under investigation.

In the AT-rich intergenic region between ORF1 and hecB $(33.7 \% \mathrm{G}+\mathrm{C})$, we found a sequence, AATAAAAGGTA ATTTATTT, that resembles the KdgR-box consensus sequence (Hugouvieux-Cotte-Pattat et al. 1996). A similar sequence, AAATAATTCGCGTTTTATT, was found in the 107bp intergenic space between hecB and hecA, which also has high AT content $(36.4 \% \mathrm{G}+\mathrm{C})$. This implies that some or all of ORF1, hecB, and hecA could be part of the KdgR regulon, which includes operons involved in pectinolysis and type II protein secretion, although this could be coincidental and requires experimental testing. Interestingly, the upstream regulatory regions of pel genes that possess KdgR-binding sites also are AT-rich (Hugouvieux-Cotte-Pattat and RobertBaudouy 1992).

To determine whether the unusual gene arrangement of the $h r p C$ and $h r p N$ region found in strain EC16 is conserved in other strains of $E$. chrysanthemi, a hot-start polymerase chain reaction procedure $\left(94^{\circ} \mathrm{C}\right.$ for $2 \mathrm{~min}$, followed by $94^{\circ} \mathrm{C}$ for 1 $\min , 55^{\circ} \mathrm{C}$ for $2 \mathrm{~min}$, and $72^{\circ} \mathrm{C}$ for $3 \mathrm{~min}$ for a total of $30 \mathrm{cy}$ cles, ending with 7 min of elongation at $72^{\circ} \mathrm{C}$ ) was performed with Taq DNA polymerase (Life Technologies, Gaithersburg, MD) and AmpliWax (Perkin-Elmer, Roche Molecular Systems, Branchburg, NJ). Primers derived from the region between $p l c A$ and $h r p F$ of EC16, 5-CTTCATTACTGAGCAA 
ATGGG-3 and 5-GTTGAAGTCATTGATGATGGC-3, amplified products of approximately $0.9 \mathrm{~kb}$ in size from genomic DNA of nine strains of $E$. chrysanthemi (Fig. 3A). In addition, strains 0-596 and 3937 produced single amplified products of slightly different sizes. Another set of primers designed from $h r p N$ and $h e c B$, 5-GATGGGTATGATCAAAAGCG-3 and 5ATGTCGTTTAACTGCTGTAACG-3, produced distinctive bands of approximately $1.2 \mathrm{~kb}$ from four strains belonging to subgroups II and III of E. chrysanthemi (Dickey 1979), including EC16 itself (Fig. 3B). Other strains produced several weak bands of various sizes. Although not definitive, these results suggest gene organizations around the $h r p C N$ region in other strains of $E$. chrysanthemi that are similar to that determined for EC16.

It is well established that diverse plant- and animalpathogenic bacteria utilize the type III pathway to secrete proteins involved in pathogenicity and virulence (Galán and Bliska 1996). Our work on the $h r p C$ operon and an earlier study with $h r c T$ (Bauer et al. 1994) confirm that the softrotting bacterium E. chrysanthemi employs a Hrp (type III) pathway. As hrp clusters generally are conserved and collinear among even distantly related bacteria such as E. amylovora and $P$. syringae (Bogdanove et al. 1996b; Kim et al. 1997), it is unexpected that $h r p$ operons of E. chrysanthemi are interrupted by genes that may function in virulence but are not known to be associated with the Hrp system. The hrpCNlinked location of $p l c A$ and $h e c B A$ supports the idea that the hrp region of E. chrysanthemi may constitute a "pathogenicity island" (Groisman and Ochman 1996) with many virulence proteins of diverse functions, controlled by diverse regulatory proteins, and secreted by diverse pathways.

\section{ACKNOWLEDGMENTS}

We thank Gail Preston for providing the HrcC and $\mathrm{HrpV}$ sequences from $P$. syringae pv. syringae and Kent Loeffler for photography. This work was supported, in part, by USDA/NRI grant 94-37303-0734 and 97-35303-4488, by Eden Bioscience Corporation, and by a grant from the Cornell Center for Advanced Technology (CAT) in Biotechnology, which is sponsored by the New York State Science and Technology Foundation and industrial partners. J. F. K. and J. H. H. were supported, in part, by Korean Government Overseas Scholarships.

\section{LITERATURE CITED}

Alfano, J. R., and Collmer, A. 1997. The type III (Hrp) secretion pathway of plant pathogenic bacteria: Trafficking harpins, Avr proteins, and death. J. Bacteriol. 179:5655-5662.

Altschul, S. F., Gish, W., Miller, W., Myers, E. W., and Lipman, D. J. 1990. Basic local alignment search tool. J. Mol. Biol. 215:403-410.

Barenkamp, S. J., and St. Geme, J. W., III. 1994. Genes encoding high molecular-weight adhesion proteins of nontypeable Haemophilus influenzae are part of gene clusters. Infect. Immun. 62:3320-3328.

Bauer, D. W., Bogdanove, A. J., Beer, S. V., and Collmer, A. 1994. Erwinia chrysanthemi hrp genes and their involvement in soft rot pathogenesis and elicitation of the hypersensitive response. Mol. PlantMicrobe Interact. 7:573-581.

Bauer, D. W., Wei, Z.-M., Beer, S. V., and Collmer, A. 1995. Erwinia chrysanthemi harpin $_{E c h}$ : An elicitor of the hypersensitive response that contributes to soft-rot pathogenesis. Mol. Plant-Microbe Interact. 8:484-491

Bergh, S., and Uhlen, M. 1992. Analysis of a polyketide synthesisencoding gene cluster of Streptomyces curacoi. Gene 117:131-136.

Bogdanove, A. J., Beer, S. V., Bonas, U., Boucher, C. A., Collmer, A., Coplin, D. L., Cornelis, G. R., Huang, H.-C., Hutcheson, S. W., Panopoulos, N. J., and Van Gijsegem, F. 1996a. Unified nomenclature for broadly conserved $h r p$ genes of phytopathogenic bacteria. Mol. Microbiol. 20:681-683.

Bogdanove, A. J., Wei, Z.-M., Zhao, L., and Beer, S. V. 1996b. Erwinia amylovora secretes harpin via a type III pathway and contains a homolog of yopN of Yersinia. J. Bacteriol. 178:1720-1730.

Dickey, R. S. 1979. Erwinia chrysanthemi: A comparative study of phenotypic properties of strains from several hosts and other Erwinia species. Phytopathology 69:324-329.

Galán, J. E., and Bliska, J. B. 1996. Cross-talk between bacterial pathogens and their host cells. Annu. Rev. Cell Dev. Biol. 12:221-255.

Groisman, E. A., and Ochman, H. 1996. Pathogenicity islands: Bacterial evolution in quantum leaps. Cell 87:791-794.

Hardie, K. R., Lory, S., and Pugsley, A. P. 1996. Insertion of an outer membrane protein in Escherichia coli requires a chaperone-like protein. EMBO J. 15:978-988.

Hirono, I., Tange, N. and Aoki, T. 1997. Iron-regulated haemolysin gene from Edwardsiella tarda. Mol. Microbiol. 24:851-856.

Huang, H.-C., He, S. Y., Bauer, D. W., and Collmer, A. 1992. The Pseudomonas syringae pv. syringae hrpH product, an envelope protein required for elicitation of the hypersensitive response in plants. J. Bacteriol. 174:6878-6885.

Huang, H.-C., Lin, R.-H., Chang, C.-J., Collmer, A., and Deng, W.-L. 1995. The complete hrp gene cluster of Pseudomonas syringae pv. syringae 61 includes two blocks of genes required for harpin ${ }_{\mathrm{Pss}}$ secretion that are arranged colinearly with Yersinia ysc homologs. Mol. Plant-Microbe Interact. 8:733-746.

Hugouvieux-Cotte-Pattat, N., Condemine, G., Nasser, W., and Reverchon, S. 1996. Regulation of pectinolysis in Erwinia chrysanthemi. Annu. Rev. Microbiol. 50:213-257.

Hugouvieux-Cotte-Pattat, N., and Robert-Baudouy, J. 1992. Analysis of the regulation of the pelBC genes in Erwinia chrysanthemi 3937. Mol. Microbiol. 6:2363-2376.

Keen, N. T., Ridgway, D., and Boyd, C. 1992. Cloning and characterization of a phospholipase gene from Erwinia chrysanthemi EC16. Mol. Microbiol. 6:179-187.

Kim, J. F. 1997. Molecular characterization of a novel harpin and two $h r p$ secretory operons of Erwinia amylovora, and a $h r p$ operon of $E$. chrysanthemi. Ph.D. thesis. Cornell University, Ithaca, NY.

Kim, J. F., Wei, Z.-M., and Beer, S. V. 1997. The $h r p A$ and $h r p C$ operons of Erwinia amylovora encode components of a type III pathway that secretes harpin. J. Bacteriol. 179:1690-1697.

King, E. O., Ward, M. K., and Raney, D. E. 1954. Two simple media for the demonstration of pyocyanin and fluorescein. J. Lab. Clin. Med. 44:301-307.

Laby, R. J., and Beer, S. V. 1992. Hybridization and functional complementation of the hrp gene cluster from Erwinia amylovora strain Ea321 and DNA of other bacteria. Mol. Plant-Microbe Interact. 5: 412-419.

Makhov, A. M., Hannah, J. H., Brennan, M. J., Trus, B. L., Kocsis, E., Conway, J. F., Wingfield, P. T., Simon, M. N., and Steven, A. C. 1994. Filamentous hemagglutinin of Bordetella pertussis: A bacterial adhe$\sin$ formed as a $50 \mathrm{~nm}$ monomeric rigid rod based on a 19-residue repeat motif rich in $\beta$-strands and turns. J. Mol. Biol. 241:110-124.

Mukherjee, A., Cui, Y., Liu, Y., and Chatterjee, A. K. 1997. Molecular characterization and expression of the Erwinia carotovora $h r p N_{E c c}$ gene, which encodes an elicitor of the hypersensitive reaction. Mol. Plant-Microbe Interact. 10:462-471.

Ried, J. L., and Collmer, A. 1987. An nptI-sacB-sacR cartridge for constructing directed, unmarked mutations in Gram-negative bacteria by marker exchange-eviction mutagenesis. Gene 57:239-246.

Russel, M. 1994. Phage assembly: A paradigm for bacterial virulence factor export? Science 265:612-614.

Wei, Z.-M., and Beer, S. V. 1993. HrpI of Erwinia amylovora functions in secretion of harpin and is a member of a new protein family. $J$. Bacteriol. 175:7958-7967.

Wei, Z.-M., Laby, R. J., Zumoff, C. H., Bauer, D. W., He, S. Y., Collmer, A., and Beer, S. V. 1992. Harpin, elicitor of the hypersensitive response produced by the plant pathogen Erwinia amylovora. Science 257:85-88

Willems, R. J. L., Geuijen, C., van der Heide, H. G. J., Renauld, G., Bertin, P., van der Akker, W. M. R., Locht, C., and Mooi, F. R. 1994. Mutational analysis of the Bordetella pertussis fim-fha gene cluster: Identification of a gene with sequence similarities to haemolysin accessory genes involved in export of FHA. Mol. Microbiol. 11:337-347. 